Економічні науки: збірник наукових праиь Луиького національного технічного університету. - Серія "Регіональна економіка". - Випуск 16 (63). - Редкол.: відп. ред. д.е.н., професор Л.Л. Ковальська - Луцьк : ІВВ Луцького НТУ, 2019. - 173 с.

УДК 330.341 .30

Павлюк Л.В., к.е.н., доцент,

Савош Л.В., к.е.н., доцент

Луцький національний технічний університет

\title{
НАПРЯМИ НАРОЩЕННЯ ВАРТОСТІ ГУДВІЛУ МАШИНОБУДІВНИХ ПІДПРИЄМСТВ РЕГІОНУ
}

У науковій публікації розглядаються питання дослідження напрямів нарощення вартості гудвілу машинобудівних підприємств регіону.

Ключові слова: гудвіл, нарощення, машинобудівні підприємства, регіон, прибутковість, господарська діяльність.

Pavliuk L., Savosh L.

\section{AREAS OF INCREASING THE VALUE OF GOODVILLE MACHINE-BUILDING ENTERPRISES OF THE REGION}

The scientific publication deals with the study of the directions of increasing the value of goodwill of machine-building enterprises of the region in order to increase their profitability. Increasing the value of goodwill at the current stage of economic development requires a great deal of attention from scientists and 
Економічні науки: збірник наукових праџь Луцького національного технічного університету. - Серія "Регіональна економіка". - Випуск 16 (63). - Редкол.: відп. ред. д.е.н., професор Л.Л. Ковальська - Луцьк : ІВВ Луцького НТУ, 2019. -173 с.

practitioners, since the proper identification of goodwill will provide accurate data on the need and opportunities for increasing it.

Goodwill value assurance should be accompanied by an analysis of the enterprise's economic activity, a diagnosis of the level of crisis, and an assessment of the effectiveness of the enterprise's development management, which must take place within the framework of a comprehensive approach and economic diagnostics.

Increasing the automation of production, purchasing new equipment, conducting certification and improving the sales system will not only expand the market, but also increase the profitability of the enterprise and increase the cost of goodwill. Also, within the framework of the conducted research, it is recommended to expand the range of products, which will significantly increase the sales volume. As a result, goodwill strongly influences the views of investors, consumers, business partners and employees themselves, which in turn increases the value and liquidity of the enterprise.

Key words: goodwill, growth, machine-building enterprises, region, profitability, economic activity.

Павлюк Л.В., Савош Л.В.

\section{НАПРАВЛЕНИЯ УВЕЛИЧЕНИЕ ГУДВИЛЛА МАШИНОСТРОИТЕЛЬНЫХ ПРЕДПРИЯТИЙ РЕГИОНА}

В научной публикации рассматриваются вопросы исследования направлений наращивания стоимости гудвилла машиностроительных предприятий региона.

Ключевые слова: гудвилл, увеличение, машиностроительные предприятия, регион, прибыльность, хозяйственная деятельность.

Постановка проблеми у загальному вигляді і її зв'язок з важливими науковими та практичними завданнями.

Для підвищення прибутковості будь-яких підприємств, i машинобудівних, зокрема, на сучасному етапі розвитку все більше уваги необхідно приділяти нарощенню вартості гудвілу. Постійний розвиток економічних та ділових відносин машинобудівних підприємств регіону, їх злиття та співпраця 3 корпораціями, а також розвиток партнерства спричинило збільшення значення вартості гудвілу.

Як відомо, нарощення вартості гудвілу передбачає підвищення прибутковості підприємств та підвищення ефективності їх діяльності. Оцінка реальної вартості активів $є$ 
Економічні науки: збірник наукових праџь Луцького національного технічного університету. - Серія "Регіональна економіка". - Випуск 16 (63). - Редкол.: відп. ред. д.е.н., професор Л.Л. Ковальська - Луцьк : ІВВ Луцького НТУ, 2019. -173 с.

ключовим фактором для прийняття управлінських рішень щодо діяльності підприємства, тому власники змушені активно опановувати систему по управлінню нематеріальними активами. Одним із таких нематеріальних активів і є гудвіл, що передбачає ділову репутацію підприємства.

Аналіз останніх досліджень, у яких започатковано вирішення проблеми.

Питанням дослідження та розробці напрямів нарощенню вартості гудвілу машинобудівних підприємств регіону, а також проблематику розроблення методологічних засад щодо гудвілу досліджували ряд вчених, а саме: С. Майєрс, Р. Брайлі, Е. Дюркгейм, С. Горін, I. Шер, О. Орлова, Т. Ковальова, О. Радіонова та багато інших.

Цілі статті. Головною ціллю статті $є$ дослідження та розробка напрямів нарощення вартості гудвілу машинобудівних підприємств регіону.

Виклад основного матеріалу дослідження 3 повним обгрунтуванням отриманих наукових результатів.

Спираючись на попередні дослідження, ми пропонуємо під «гудвілом» розуміти сукупність важливих елементів бізнесу, що стимулюють клієнтів продовжувати користуватися послугами підприємства і дозволяють отримати таку величину прибутку, яка $є$ більшою, ніж необхідно для нормального доходу на всі активи підприємства, включаючи дохід на всі нематеріальні активи, які можуть бути ідентифіковані та оцінені [1].

Здійснивши аналіз господарської діяльності основних машинобудівних підприємств регіону, ми прийшли до висновку, що усі вони потерпають від більш-менш однакового кола проблем, а саме:

- обмеженості у здійсненні незалежної господарської діяльності підприємств;

- високої собівартості продукції;

- високих витрат на збут продукції;

- неефективного

використання

виробничих потужностей; 
Економічні науки: збірник наукових праџь Луцького національного технічного університету. - Серія "Регіональна економіка". - Випуск 16 (63). - Редкол.: відп. ред. д.е.н., професор Л.Л. Ковальська - Луцьк : ІВВ Луцьккого НТУ, 2019. -173 с.

- відсутності максимального синергетичного ефекту;

- високого коефіцієнту наявного застарілого обладнання;

- низької заробітної плати (у порівнянні 3 іншими виробничими підприємствами);

- відсутності спеціалізованого обладнання, за допомогою якого можна виявити найменший брак продукції тощо.

Зважаючи на те, що фактори, які формують вартість гудвілу не піддаються ідентифікації, більшість 3 них мають безпосереднє відношення до конкретних активів. Наприклад, високу якість продукції забезпечує репутація торгового імені чи фірмової марки тощо. Варто відзначити, що оцінка вартості гудвілу проводиться під час купівлі або продажу підприємства. Особливістю оцінювання є те, що результат має об'єктивно суб'єктивний характер, оскільки визначити точну цифру щодо збільшенні прибутків через зміну вартості гудвілу неможливо. На основі досліджених наукових праць, спробуємо сформувати головні напрями нарощення вартості гудвілу машинобудівних підприємств регіону у таблиці $1[2,3]$.

Таблиця 1

Напрями нарощення вартості гудвілу машинобудівних підприємств регіону і їх очікувані наслідки

\begin{tabular}{|l|c|}
\hline $\begin{array}{c}\text { Використаний напрям нарощення } \\
\text { вартості гудвілу підприємства }\end{array}$ & $\begin{array}{c}\text { Вплив на } \\
\text { збільшення обсягів } \\
\text { реалізації продукції, } \\
\%\end{array}$ \\
\hline Сертифікація продукції (ISO) & $15,0 \%$ \\
\hline Використання методів VW & $2,0 \%$ \\
\hline Використання досвіду Hino Motors & $1,5 \%$ \\
\hline Співпраця з Arvin Meritor & $3,4 \%$ \\
\hline Suspensys Sistemas Automotivos LtdA & $1,6 \%$ \\
\hline Виставки та експозиції & $9,0 \%$ \\
\hline
\end{tabular}


Економічні науки: збірник наукових праџь Луцького національного технічного університету. - Серія "Регіональна економіка". - Випуск 16 (63). - Редкол.: відп. ред. д.е.н., професор Л.Л. Ковальська - Луцьк : ІВВ Луцьккого НТУ, 2019. -173 с.

Отже, дослідження показують, що результати використання напрямів нарощення вартості гудвілу підприємства є досить вдалими та ефективними. Спираючись на ці дані, можна здійснити прогноз збільшення ефективності діяльності машинобудівних підприємств регіону на базі нарощення вартості гудвілу через використання цих методів (табл. 2).

Таблиця 2

Ефективність використання напрямів нарощення вартості гудвілу машинобудівних підприємств регіону

\begin{tabular}{|l|c|}
\hline $\begin{array}{c}\text { Використаний метод } \\
\text { нарощення вартості гудвілу } \\
\text { підприємства }\end{array}$ & $\begin{array}{c}\text { Вплив на збільшення обсягів } \\
\text { реалізації продукції, \% }\end{array}$ \\
\hline Розширення асортименту & $28,0 \%$ \\
\hline Сертифікація & $4,0 \%$ \\
\hline $\begin{array}{l}\text { Покращення } \\
\text { діяльності }\end{array} \quad$ збутової \\
\hline $\begin{array}{l}\text { Обладнання по виявленню } \\
\text { браку }\end{array}$ & $1,2 \%$ \\
\hline Покращення сервісу & $2,0 \%$ \\
\hline Виставки & $8,0 \%$ \\
\hline
\end{tabular}

Необхідно зазначити, що досліджуючи напрями нарощення вартості гудвілу, ми виявили певні його особливості, a саме:

1. Багатофакторний характер гудвілу має на увазі, що дане поняття включає в себе певний ряд чинників та елементів, що впливають на його зростання чи зниження.

2. Гудвіл $€$ невід'ємно пов'язаний 3 конкретним підприємством і виникає, коли це підприємство має певні конкурентні переваги, що в майбутньому дозволяє отримувати більші прибутки.

3. Умовна вартість гудвілу. Наприклад, вартість гудвілу зростає, коли відбувається злиття чи продаж підприємства за 
Економічні науки: збірник наукових праџь Луцького національного технічного університету. - Серія "Регіональна економіка". - Випуск 16 (63). - Редкол.: відп. ред. д.е.н., професор Л.Л. Ковальська - Луцьк : ІВВ Луиького НТУ, 2019. - 173 с.

умови, що вартість підприємства перевищує фактичну вартість його активів.

4. Неможливість прибуткового функціонування підприємства без нарощення вартості гудвілу тощо.

Згідно Закону України «Про оподаткування прибутку підприємств», гудвіл є також «комплекс заходів, спрямований на збільшення прибутку підприємства, без відповідного збільшення активних операцій, включаючи використання кращих управлінських здібностей, домінуючу позицію на ринку продукції (робіт, послуг), нові технології тощо. Вартість гудвілу визначається як різниця між ціною придбання i звичайною ціною відповідних активів» $[4,5]$.

Тому, для машинобудівних підприємств регіону доречно повсякчасно розширювати асортимент продукції, яка реалізується підприємствами як окремими господарюючими суб'єктами. В той же час, для збільшення прибутку таких підприємств слід розглянути технічне забезпечення цехів, що потребують модернізації. Адже коли підприємство прагне відповідати європейським стандартам, то рано чи пізно воно буде змушене повністю переобладнати цехи, замінивши старе обладнання на нове, тим самим підвищивши рівень безпеки виробництва на підприємстві, а також задоволення працівників умовами своєї праці [6].

Важливим фактором впливу на нарощення вартості гудвілу підприємства, $є$ собівартість продукції, адже після модернізації та заміни старого обладнання, вона, як правило, знижується, що пов'язано із значним зменшенням витрат на ремонтні послуги. Також $з$ встановленням нових виробничих ліній є всі шанси зменшити рівень браку. Отож, своєчасна модернізація обладнання та зниження собівартості значно наростять вартість гудвілу машинобудівних підприємств регіону, що позитивно вплине на збільшення прибутку [7].

Висновки. Отож, 3 метою нарощення вартості гудвілу машинобудівних підприємств регіону та для підвищення прибутковості і посилення конкурентних позицій, пропонуємо ряд заходів: 
Економічні науки: збірник наукових праць Луиького національного технічного університету. - Серія "Регіональна економіка". - Випуск 16 (63). - Редкол.: відп. ред. д.е.н., професор Л.Л. Ковальська - Луцьк : ІВВ Луцьккого НТУ, 2019. -173 с.

\section{1. Провести максимальну автоматизацію усіх виробництв.}

2. Здійснити закупівлю спеціалізованого обладнання, що дозволить більш ефективно і 3 мінімальними затратами випускати необхідну продукцію.

3. Повсякчасне застосування PR-технологій для підтримки високого іміджу торгової марки.

4. Покращення системи сервісного обслуговування.

5. Максимально можливе зниження цін готової продукції за рахунок зниження собівартості.

6. Проведення додаткового навчання по підвищенню професійної майстерності та кваліфікації працівників, обмін працівниками для набуття ними нового досвіду роботи.

7. Розширення асортименту випущеної продукції, що дозволить розширити ринки збуту.

8. Збільшення інтенсивності використання активів, оборотних активів, власного капіталу, дебіторської заборгованості, мінімізація залишків готової продукції.

9. Покращення маркетингової діяльності, що в свою чергу, збільшить обсяги збуту, використання новітніх систем менеджменту, як наприклад, SixSigma, що функціонує на багатьох машинобудівних підприємствах регіону тощо.

1. Павлюк Л.В., Завадська О.М. Значення гудвілу та його оцінка для здійснення успішної підприємницької діяльності / Економічний форум / науковий журнал, 2019. №2. С. 94-99.

2. Десмонда Г.М. та Келлі Р.Е., Формування вартості гудвілу / Пер. 3 англ.: Уч. пос. М.: Видавничий дім «Вільямс», 2001256 с.

3. Бланк I.О. Оцінка вартості гудвілу підприємства. Методика розрахунку вартості гудвілу / Пер. 3 англ. А. Олійника та Р. Скіпальського. К.: Основи, 20149 с.

4. Електронний pecypc: https://zakon.rada.gov.ua/laws/show/247/95\%D0\%B2\%D1\%80/ed19950714/find?text=\%C3\%F3\%E4\%E2\%B3\%EB\#w11

5. Положення (стандарт) бухгалтерського обліку № 8 «Нематеріальні активи»: Положення, затверджене Наказом Міністерства фінансів України від 31.03.99 № 87. [Електронний ресурс]. Режим доступу: www.rada.gov.ua.

6. Нусінова О.В. Оцінювання репутації [Електронний ресурс]. / Оцінювання репутації підприємства: кількісні та якісні підходи, 2014. Режим доступу http://studme.com.ua/ . 
Економічні науки: збірник наукових праць Луиького національного технічного університету. - Серія "Регіональна економіка". - Випуск 16 (63). - Редкол.: відп. ред. д.е.н., професор Л.Л. Ковальська - Луцьк : ІВВ Луиького НТУ, 2019. -173 с.

7. Корчемлюк А.І., Литвинчук І.Л., Циганенко Г.В. Гудвіл корпоративних підприємств: монографія / Житомир, 2013. 160 с. 